\title{
Extensive renal and ureteral calcification due to tuberculosis: rare images for an uncommon condition
}

\author{
Jai Prakash, Apul Goel, Satyanarayan Sankhwar, Bhupendra Pal Singh
}

Department of Urology, King George Medical University, Lucknow Uttar Pradesh, India

\section{Correspondence to} Professor Apul Goel, drapul.goel@gmail.com
To cite: Prakash J, Goel A, Sankhwar S, et al. BMJ Case Rep Published online:

[please include Day Month Year] doi:10.1136/bcr-2012008508

\section{DESCRIPTION}

A 25-year-old man with a history of treated pulmonary tuberculosis presented with dull-aching right flank pain for the last 2 years. Urine examination showed acid-fast bacilli and culture was positive for Mycobacterium tuberculosis. The serum creatinine was normal and the intravenous urogram (IVU) showed an extensive right renal and ureteral calcification, non-excreting right kidney and normal left kidney and bladder (figure 1). A CT scan confirmed the findings of IVU (figure 2). As the renal scan revealed a right non-functioning kidney, the patient was managed by four drug antitubercular therapy (ATT) followed by right nephroureterectomy (figure 3).

Today, urinary tuberculosis is infrequent and renal calcification is not uncommon, but associated ureteral calcifications are rare. ${ }^{1}$ IVU has traditionally been the gold standard tool to diagnose and evaluate urinary tuberculosis, but CT is the most sensitive method of identifying renal/ureteral calcification. ${ }^{1}$ In our case, owing to extensive disease, the calcification was clearly visible on the IVU. Calcification in the ureteral wall may also be seen in schistosomiasis, but calcification of the kidney extending along the ureter is virtually diagnostic of tuberculosis. ${ }^{2}$ Ureteral calcification in tuberculosis is intraluminal and appears as a cast of the ureter, which is thickened and not dilated. ${ }^{3}$

This patient had received complete ATT for pulmonary tuberculosis. Despite this, he developed extensive renal disease. Therefore, in patients with a history of treated primary tuberculosis, physicians should be highly suspicious for tuberculosis in other organs to avoid irreversible damage, and in case of 'Acid Sterile Pyuria', culture for tuberculosis must be done.

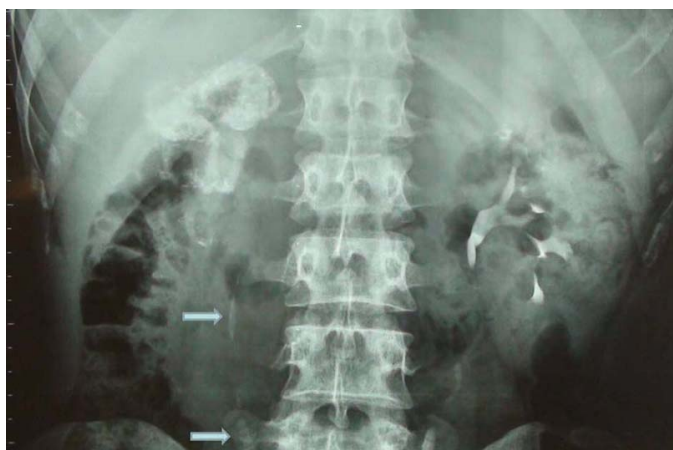

Figure 1 Intravenous urogram showing right renal and ureteral calcification (arrow) with a normal left kidney and ureter.

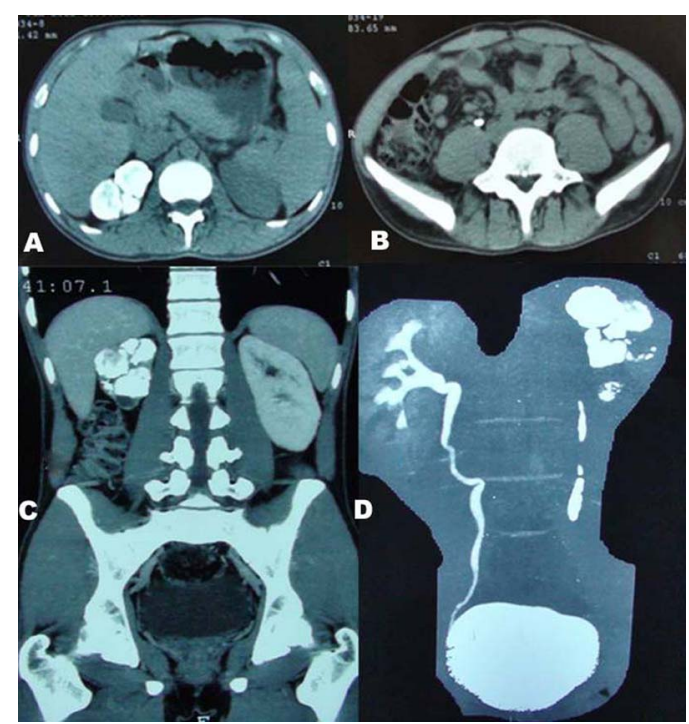

Figure 2 (A) Axial non-contrast CT image showing renal calcification. (B) Non-contrast axial cut showing ureteral calcification. (C) Reconstructed image showing right renal calcification. (D) Reconstructed CT urogram image showing extensive right renal and ureteral calcification (rotated image).

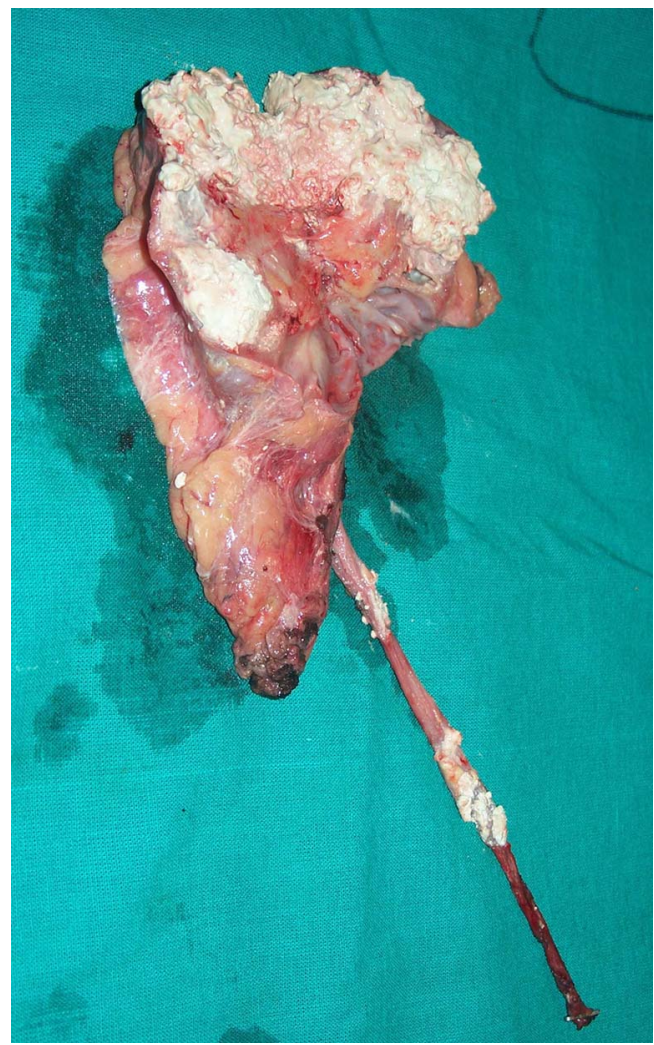

Figure 3 Removed specimen showing extensive renal and ureteral calcification. 


\section{Learning points}

- Tuberculosis is a systemic disease that can involve any organ of the body. Therefore, full evaluation of patients (including for urinary tuberculosis) is important in patients with a history of primary tuberculosis.

- Extensive calcification of the kidney along with ureter is a rare and important finding in diagnosis of urinary tuberculosis.

- In case of 'Acid Sterile Pyuria', there must be a very strong suspicion for renal tuberculosis, and a culture for Mycobacterium tuberculosis must be conducted.
Competing interests None.

Patient consent Obtained.

Provenance and peer review Not commissioned; externally peer reviewed.

\section{REFERENCES}

1 Mc Aleer SJ, Johnson CW, Johnson WD. Tuberculosis and parasitic and fungal infections of the genitourinary system. In: Wein AJ, Kavoussi LR, Novick AC, Partin AW, Peters CA. eds. Campbell-Walsh urology. Philadelphia: Saunders Elsevier, 2007:436-70.

2 Merchant SA. Tuberculosis of the genitourinary system. Indian J Radiol Imaging, 1993;3:275-86.

3 Cate HW. Tuberculosis of the genitourinary tract. In: Emmett JL, Witten DM, eds. Clinical Urography. Philadelphia: WB Saunders, 1971:855-928.

Copyright 2013 BMJ Publishing Group. All rights reserved. For permission to reuse any of this content visit http://group.bmj.com/group/rights-licensing/permissions.

BMJ Case Report Fellows may re-use this article for personal use and teaching without any further permission.

Become a Fellow of BMJ Case Reports today and you can:

- Submit as many cases as you like

- Enjoy fast sympathetic peer review and rapid publication of accepted articles

- Access all the published articles

- Re-use any of the published material for personal use and teaching without further permission

For information on Institutional Fellowships contact consortiasales@bmjgroup.com

Visit casereports.bmj.com for more articles like this and to become a Fellow 